Article

\title{
Preparation and Characterization of Magnetic $\mathrm{Fe}_{3} \mathrm{O}_{4} / \mathrm{CdWO}_{4}$ and $\mathrm{Fe}_{3} \mathrm{O}_{4} / \mathrm{CdWO}_{4} / \mathrm{PrVO}_{4}$ Nanoparticles and Investigation of Their Photocatalytic and Anticancer Properties on PANC1 Cells
}

\author{
Mohammad Amin Marsooli 1,2, Mahdi Fasihi-Ramandi ${ }^{3}$, Kourosh Adib ${ }^{4}$, Saeid Pourmasoud ${ }^{5}$, \\ Farhad Ahmadi 6,7, Mohammad Reza Ganjali 8,9, Ali Sobhani Nasab 10,11(D), \\ Mahdi Rahimi Nasrabadi ${ }^{1,2, *}$ and Marta E. Plonska-Brzezinska ${ }^{12, *(D)}$ \\ 1 Nanobiotechnology Research Center, Baqiyatallah University of Medical Sciences, Tehran 1951683759, Iran; \\ mohammadamin.marsuli@gmail.com \\ 2 Faculty of Pharmacy, Baqiyatallah University of Medical Sciences, Tehran 6461853090, Iran \\ 3 Molecular Biology Research Center, System Biology and Poisoning Institute, Baqiyatallah University of \\ Medical Sciences, Tehran 1951683759, Iran; fasihi.m@gmail.com \\ 4 Department of Chemistry, Imam Hossein University, Tehran 1955735345, Iran; k_anbaz@yahoo.com \\ 5 Department of Physics, University of Kashan, Kashan 8731753153, Iran; \\ SA_POURMASOUD2007@yahoo.com \\ 6 Physiology Research Center, Iran University of Medical Sciences, Tehran 1449614535, Iran; \\ Farhadahmadi55@gmail.com \\ 7 Department of Medicinal Chemistry, School of Pharmacy-International Campus, Iran University of Medical \\ Sciences, Tehran 1451555763, Iran \\ 8 Center of Excellence in Electrochemistry, Faculty of Chemistry, University of Tehran, Tehran 1951683759, \\ Iran; Ganjali@gmail.com \\ 9 Biosensor Research Centre, Endocrinology \& Metabolism Molecular and Cellular Research Institute, \\ Tehran University of Medical Sciences, Tehran 1951683759, Iran \\ 10 Social Determinants of Health (SDH) Research Center, Kashan University of Medical Sciences, \\ Kashan 8115187159, Iran; Ali.sobhaninasab@gmail.com \\ 11 Core Research Lab, Kashan University of Medical Sciences, Kashan 8115187159, Iran \\ 12 Department of Organic Chemistry, Faculty of Pharmacy with the Division of Laboratory Medicine, \\ Medical University of Bialystok, Mickiewicza 2A, 15-222 Bialystok, Poland \\ * Correspondence: rahimi@bmsu.ac.ir (M.R.N.); marta.plonska-brzezinska@umb.edu.pl (M.E.P.-B.); \\ Tel.: +98-2182483409 (M.R.N.)
}

Received: 6 September 2019; Accepted: 4 October 2019; Published: 8 October 2019

\begin{abstract}
Fe}_{3} \mathrm{O}_{4} / \mathrm{CdWO}_{4}$ and $\mathrm{Fe}_{3} \mathrm{O}_{4} / \mathrm{CdWO}_{4} / \mathrm{PrVO}_{4}$ magnetic nanoparticles were prepared at different molar ratios of $\mathrm{PrVO}_{4}$ to previous layers $\left(\mathrm{Fe}_{3} \mathrm{O}_{4} / \mathrm{CdWO}_{4}\right)$ via the co-precipitation method assisted by a sonochemical procedure, in order to investigate the photocatalytic performance of these systems and their cytotoxicity properties. The physico-chemical properties of these magnetic nanoparticles were determined via several experimental methods: X-ray diffraction, energy dispersive X-ray spectroscopy, Fourier transformation infrared spectroscopy and ultraviolet-visible diffuse reflection spectroscopy, using a vibrating sample magnetometer and a scanning electron microscope. The average sizes of these nanoparticles were found to be in the range of $60-100 \mathrm{~nm}$. The photocatalytic efficiency of the prepared nanostructures was measured by methylene blue degradation under visible light (assisted by $\mathrm{H}_{2} \mathrm{O}_{2}$ ). The magnetic nanosystem with a 1:2:1 ratio of three oxide components showed the best performance by the degradation of ca. $70 \%$ after $120 \mathrm{~min}$ of exposure to visible light irradiation. Afterwards, this sample was used for the photodegradation of methyl orange, methyl violet, fenitrothion, and rhodamine-B pollutants. Finally, the mechanism of the photocatalytic
\end{abstract}


reaction was examined by releasing ${ }^{\bullet} \mathrm{OH}$ under $\mathrm{UV}$ light in a system including terephthalic acid, as well as $\mathrm{O}^{2-}, \mathrm{OH}$, and hole scavengers. Additionally, the cytotoxicity of each synthesized sample was assessed using a 3-(4,5-dimethylthiazol-2-yl)-2,5-diphenyltetrazolium bromide assay against the human cell line PANC1 (cancer), and its IC50 was approximately $125 \mathrm{mg} / \mathrm{L}$.

Keywords: magnetic nanoparticle; $\mathrm{Fe}_{3} \mathrm{O}_{4} / \mathrm{CdWO}_{4} ; \mathrm{Fe}_{3} \mathrm{O}_{4} / \mathrm{CdWO}_{4} / \mathrm{PrVO}_{4}$; sonochemical procedure; photocatalysis; methylene blue; cytotoxicity properties; MTT assay; human cell line; PANC1 cells

\section{Introduction}

Obtaining aseptic conditions for several commercial products is the main factor associated with public health problems. In recent years, several researchers have attempted to discover and develop new strategies against organic pollutants [1-3]. The cosmetics, leather, paper, plastics, and textile industries, among others, produce many pollutants, including colour contaminants, that are carcinogenic to mammals due to their use of dyestuffs and chemical materials $[4,5]$. Nanoparticles that are effective for combining various original properties in a single nanoplatform have received considerable attention $[1,4,5]$. Currently, one of the most investigated tools to eliminate harmful contaminants from water are photocatalytic materials [6-19]. Magnetic nanoparticles act as heterogeneous catalysts that can easily separate a catalyst from a reaction system with the aid of an added magnetic field [19-22]. Furthermore, the use of $\mathrm{H}_{2} \mathrm{O}_{2}$ to improve photocatalytic results under visible and UV light has been reported in previous studies [23,24].

Semiconductor materials such as $\mathrm{ZnS}, \mathrm{TiO}_{2}, \mathrm{WO}_{3}$, and $\mathrm{CdS}$ are promising candidates for the degradation of contaminated environments via photocatalytic reactions $[25,26]$. For example, transition metal-based orthovanadates $\left(\mathrm{MVO}_{4}\right)$ such as $\mathrm{PrVO}_{4}$ have the potential to be applied in several fields, including the gas-sensor, solar-cell, catalyst, photoluminescent, and photocatalyst fields [27-31].

$\mathrm{CdWO}_{4}$ and some of its composites have shown considerable potential for the photocatalytic degradation of some of the colours under visible and $\mathrm{UV}$ irradiation [32-34]. $\mathrm{CdWO}_{4}$ showed its great potential in its physicochemical behavior resulting from the self-trapped excitons [32,35]. $\mathrm{CdWO}_{4}$, which crystallizes in a monoclinic wolframite structure, has substantial chemical, optical, and structural properties [32,36]. Its energy band gap is bigger than common photocatalysts like $\mathrm{TiO}_{2}$, suggesting that it would have a low photo-absorption activity $[23,24]$. Nonetheless, $\mathrm{CdWO}_{4}$ is able to be excited via a considerable amount of energy which is higher than its band gap, generating high energy electron-hole pairs. Therefore, this compound has a considerable photocatalytic activity for removing several contaminants and dyes from water, resulting in turning poisonous pollutants into safe compounds such as $\mathrm{H}_{2} \mathrm{O}$ as well as $\mathrm{CO}_{2}[20,37]$. However, the quick recombination ratios of generated charge carriers as well as the inadequate response to visible rays can decrease the usage of $\mathrm{CdWO}_{4}$. The photocatalytic productivity of rare earth elements doped with $\mathrm{CdWO}_{4}$ is bigger than that of undoped samples for degrading organic pollutants $[1,10,38]$.

Cancer is an important public health threat affecting global disability and mortality rates. Pancreatic cancer shows a high incidence worldwide. It has been shown that new therapeutic approaches are needed to complement the current therapeutic tools. Targeting cancer cells is one of the most important uses of nanoscale-designed materials $[39,40]$. Nanoparticles are very promising since they can perform as drug carriers and sono- and photosensitizers [41-43]. In these last two cases, the formation of reactive oxygen species is observed as a result of electromagnetic radiation excitation with ultrasound activation or an adequate wavelength, respectively $[41,43]$. Due to the interesting physicochemical properties, excellent stability under physiological conditions and high biocompatibility at a low material complexity of inorganic nanoparticles, they may be used in cancer therapy. Since then, the most frequently used have been titanium dioxide [41,42,44], zinc oxide [41], and tungstate nanoparticles [45-48]. 
This study reports the synthesis of $\mathrm{Fe}_{3} \mathrm{O}_{4} / \mathrm{CdWO}_{4}$ (signed as S1) and $\mathrm{Fe}_{3} \mathrm{O}_{4} / \mathrm{CdWO}_{4} / \mathrm{PrVO}_{4}$ magnetic nanocomposites with varying molar ratios of $\mathrm{PrVO}_{4}$ (1:2:0.5 (S2); 1:2:0.75 (S3); 1:2:1 (S4); and 1:2:1.5 (S5)) with an enhanced photocatalytic activity under visible light irradiation. The morphological, structural, magnetic, optical and cytotoxic properties of the optimized sample were obtained using scanning electron microscopy (SEM), X-ray diffraction (XRD), an energy dispersive analysis of X-rays (EDX), Fourier transformation infrared spectroscopy (FT-IR), vibrating sample magnetometry (VSM), and UV-Vis diffuse reflection spectroscopy (DRS). Two types of pollutants, methylene blue (MB) and methyl violet $(\mathrm{MV})$, were used to evaluate the photocatalytic activity of the samples under visible light irradiation (assisted by $\mathrm{H}_{2} \mathrm{O}_{2}$ ). Additionally, in order to assess the efficiency of the synthesized samples under ultraviolet light, the samples with the contaminants MB, fenitrothion (FNT), methyl orange $(\mathrm{MO})$, and rhodamine- $\mathrm{B}(\mathrm{RhB})$ were tested. The photocatalytic behaviour mechanism was investigated using the conversion test of terephthalic acid (TA) to 2-hydroxy-TA in the presence of hydroxyl radicals and the employment of ${ }^{\bullet} \mathrm{O}^{2-}, \cdot \mathrm{OH}$, and hole scavengers. Additionally, the 3-(4,5-dimethylthiazol-2-yl)-2,5-diphenyltetrazolium bromide (MTT) assay was performed on a PANC1 cell line on S4 nanoparticles to calculate the cytotoxicity effect on mammalian cancer cells.

\section{Materials and Methods}

\subsection{Materials}

Unless noted, all chemicals and solvents were commercially available and used as received without further purification from Sigma, Germany. We used iron (III) chloride hexahydrate $\left(\mathrm{FeCl}_{3} \cdot 6 \mathrm{H}_{2} \mathrm{O}\right)$ $(99 \%)$, iron(II) chloride tetrahydrate $\left(\mathrm{FeCl}_{2} \cdot 4 \mathrm{H}_{2} \mathrm{O}\right)(99 \%)$, sodium hydroxide $(\mathrm{NaOH})(98 \%)$, cadmium nitrate tetrahydrate $\left(\mathrm{Cd}\left(\mathrm{NO}_{3}\right)_{2} \cdot 4 \mathrm{H}_{2} \mathrm{O}\right)(99 \%)$, sodium tungstate dehydrate $\left(\mathrm{Na}_{2} \mathrm{WO}_{4} \cdot 2 \mathrm{H}_{2} \mathrm{O}\right)(99 \%)$, praseodymium (III) nitrate hexahydrate $\left(\operatorname{Pr}\left(\mathrm{NO}_{3}\right)_{3} \cdot 6 \mathrm{H}_{2} \mathrm{O}\right)(99 \%)$, ammonium metavanadate $\left(\mathrm{NH}_{4} \mathrm{VO}_{3}\right)$ $(99 \%)$, methyl orange (MO) $(99 \%)$, methylene blue (MB) $(99 \%)$, methyl violet (MV) $(99 \%)$, fenitrothion (FNT) (99\%), rhodamine B (RhB) (99\%), foetal bovine serum (FBS) $(99 \%)$, penicillin $(99 \%)$, streptomycin (99\%), trypsin (99\%), 2,2', $2^{\prime \prime}, 2^{\prime \prime \prime}$-(ethane-1,2-diyldinitrilo) tetraacetic acid (EDTA) (99\%), 3-(4,5-dimethylthiazol-2-yl)-2,5-diphenyltetrazolium bromide (MTT) (99\%), acetone (99.8\%) and ethanol $(99.8 \%)$. All aqueous solutions were made using deionized water, which was further purified with a Milli-Q system (Millipore).

\subsubsection{Preparation of $\mathrm{Fe}_{3} \mathrm{O}_{4}$ Nanoparticles}

First, 0.01 moles of $\mathrm{FeCl}_{3} \cdot 6 \mathrm{H}_{2} \mathrm{O}$ and 0.005 moles of $\mathrm{FeCl}_{2} \cdot 4 \mathrm{H}_{2} \mathrm{O}$ were dissolved in $200 \mathrm{~mL}$ of distilled water and transferred to a three-neck flask [49]. A mechanical stirrer was used for stirring the solution for $60 \mathrm{~min}$. Then, by adding $2 \mathrm{M} \mathrm{NaOH}$ at $30{ }^{\circ} \mathrm{C}$ in the presence of gaseous $\mathrm{N}_{2}$, the precipitation process was carried out. The reaction system was kept at $70^{\circ} \mathrm{C}$ for $5 \mathrm{~h}$, and the $\mathrm{pH}$ of the solution was \pm 12 . Afterward, the system was cooled to room temperature, and the precipitation was separated via a permanent magnet and washed with distilled water until the $\mathrm{pH}$ was 7 . Finally, the $\mathrm{Fe}_{3} \mathrm{O}_{4}$ nanoparticles were washed with acetone and dried at $70{ }^{\circ} \mathrm{C}$.

\subsubsection{Preparation of $\mathrm{Fe}_{3} \mathrm{O}_{4} / \mathrm{CdWO}_{4}$ Nanoparticles}

First, 0.001 moles of $\mathrm{Fe}_{3} \mathrm{O}_{4}$ nanoparticles were dispersed by ultrasonication in $50 \mathrm{~mL}$ of distilled water. Then, $50 \mathrm{~mL}$ of $\mathrm{Cd}\left(\mathrm{NO}_{3}\right)_{2} \cdot 4 \mathrm{H}_{2} \mathrm{O}(0.04 \mathrm{M}$ solution) was added to the container containing the $\mathrm{Fe}_{3} \mathrm{O}_{4}$ nanoparticles. Afterward, $50 \mathrm{~mL}$ of $\mathrm{Na}_{2} \mathrm{WO}_{4} \cdot 2 \mathrm{H}_{2} \mathrm{O}(0.04 \mathrm{M}$ solution) was added dropwise to the mixture, while a magnetic mixer stirred the contents at room temperature. The precipitation was separated by the magnet, washed with distilled water and ethanol, and dried at $80^{\circ} \mathrm{C}$. Sediments were placed at $550{ }^{\circ} \mathrm{C}$ for $3 \mathrm{~h}$ for calcinations. 


\subsubsection{Preparation of $\mathrm{Fe}_{3} \mathrm{O}_{4} / \mathrm{CdWO}_{4} / \mathrm{PrVO}_{4}$ Nanoparticles}

In situ co-precipitation (assisted by the ultrasonic approach) was used for the preparation of these nanoparticles. First, $0.544 \mathrm{~g}$ of noncalcified as-prepared $\mathrm{Fe}_{3} \mathrm{O}_{4} / \mathrm{CdWO}_{4}$ (sample S1) was dispersed in $70 \mathrm{~mL}$ of distilled water under ultrasonic irradiation for $15 \mathrm{~min}$. Then, in two separate containers, $50 \mathrm{~mL}$ of $0.01 \mathrm{M} \mathrm{NH}_{4} \mathrm{VO}_{3}$ and $\operatorname{Pr}\left(\mathrm{NO}_{3}\right)_{3} \cdot 6 \mathrm{H}_{2} \mathrm{O}$ were prepared to obtain sediments with a molar ratio of 1:2:0.5 (sample S2), and the $\mathrm{NH}_{4} \mathrm{VO}_{3}$ solution was added to the dispersed nanoparticles. The ultrasonic probe was placed in the mixture for the generation of ultrasonic waves with a frequency and power of $20 \mathrm{KHz}$ and $400 \mathrm{~W}$, respectively. The contents of the $\operatorname{Pr}\left(\mathrm{NO}_{3}\right)_{3} \cdot 6 \mathrm{H}_{2} \mathrm{O}$ solution were added dropwise to the reaction vessel for $5 \mathrm{~min}$ and then exposed to ultrasound irradiation for $15 \mathrm{~min}$. To fabricate sediments with various molar ratios, quantities of $0.087 \mathrm{~g} \mathrm{NH}_{4} \mathrm{VO}_{3}$ and $0.325 \mathrm{~g} \operatorname{Pr}\left(\mathrm{NO}_{3}\right)_{3} \cdot 6 \mathrm{H}_{2} \mathrm{O}$ (with molar ratios of 1:2:0.75, sample S3), $0.117 \mathrm{~g} \mathrm{NH}_{4} \mathrm{VO}_{3}$ and $0.44 \mathrm{~g} \operatorname{Pr}\left(\mathrm{NO}_{3}\right)_{3} \cdot 6 \mathrm{H}_{2} \mathrm{O}(1: 2: 1$, sample S4), as well as $0.175 \mathrm{~g} \mathrm{NH}_{4} \mathrm{VO}_{3}$ and $0.651 \mathrm{~g} \operatorname{Pr}\left(\mathrm{NO}_{3}\right)_{3} \cdot 6 \mathrm{H}_{2} \mathrm{O}$ (1:2:1.5, sample S5) were used in the same approach. The sediments were separated with a magnet, washed with distilled water and ethanol, and then dried in the oven at $75^{\circ} \mathrm{C}$. Finally, the synthesized nanoparticles were placed at $550^{\circ} \mathrm{C}$ for $3 \mathrm{~h}$.

To achieve a more accurate understanding of the synthesis of nanocomposites, the proposed mechanism is expressed as follow:

$$
\begin{aligned}
& \mathrm{Fe}\left(\mathrm{NO}_{3}\right)_{3} \cdot 9 \mathrm{H}_{2} \mathrm{O}+\mathrm{H}_{2} \mathrm{O} \rightarrow \mathrm{Fe}^{3+}+3 \mathrm{NO}_{3}{ }^{-}+10 \mathrm{H}_{2} \mathrm{O} \\
& \mathrm{Fe}\left(\mathrm{NO}_{3}\right)_{2} \cdot 9 \mathrm{H}_{2} \mathrm{O}+\mathrm{H}_{2} \mathrm{O} \rightarrow \mathrm{Fe}^{2+}+2 \mathrm{NO}_{3}^{-}+10 \mathrm{H}_{2} \mathrm{O} \\
& \mathrm{Fe}^{2+}+\mathrm{Fe}^{3+}+5 \mathrm{NaOH}+5 \mathrm{NO}_{3}{ }^{-}+\mathrm{H}_{2} \mathrm{O} \rightarrow \mathrm{Fe}(\mathrm{OH})_{2}+\mathrm{Fe}(\mathrm{OH})_{3}+5 \mathrm{NaNO}_{3} \\
& \mathrm{Fe}(\mathrm{OH})_{2}+2 \mathrm{Fe}(\mathrm{OH})_{3}+\Delta \rightarrow \mathrm{Fe}_{3} \mathrm{O}_{4}+4 \mathrm{H}_{2} \mathrm{O} \\
& \mathrm{Cd}\left(\mathrm{NO}_{3}\right)_{2} \cdot 6 \mathrm{H}_{2} \mathrm{O}+\mathrm{H}_{2} \mathrm{O} \rightarrow \mathrm{Cd}^{2+}+2 \mathrm{NO}_{3}^{-}+7 \mathrm{H}_{2} \mathrm{O} \\
& \mathrm{Na}_{2} \mathrm{WO}_{4} \cdot 2 \mathrm{H}_{2} \mathrm{O}+\mathrm{H}_{2} \mathrm{O} \rightarrow 2 \mathrm{Na}^{+}+\mathrm{WO}_{4}^{2-}+3 \mathrm{H}_{2} \mathrm{O} \\
& \mathrm{Cd}^{2+}+\mathrm{WO}_{4}^{2-} \rightarrow \mathrm{CdWO}_{4} \\
& \mathrm{NH}_{4}{ }^{+}+\mathrm{NO}_{3}{ }^{-} \rightarrow \mathrm{NH}_{4} \mathrm{NO}_{3} \\
& \operatorname{Pr}\left(\mathrm{NO}_{3}\right)_{3} \cdot 6 \mathrm{H}_{2} \mathrm{O}+\mathrm{H}_{2} \mathrm{O} \rightarrow \mathrm{Pr}^{3+}+3 \mathrm{NO}_{3}^{-}+7 \mathrm{H}_{2} \mathrm{O} \\
& \mathrm{NH}_{4} \mathrm{VO}_{3}+\mathrm{H}_{2} \mathrm{O} \rightarrow \mathrm{NH}_{4}^{+}+\mathrm{VO}_{3}^{-}+\mathrm{H}_{2} \mathrm{O} \\
& \mathrm{Pr}^{3+}+\mathrm{VO}_{4}^{3-} \rightarrow \mathrm{PrVO}_{4} \\
& \operatorname{Pr}\left(\mathrm{NO}_{3}\right)_{3} \cdot 6 \mathrm{H}_{2} \mathrm{O}+3 \mathrm{NH}_{4} \mathrm{VO}_{3}+\mathrm{Fe}\left(\mathrm{NO}_{3}\right)_{3} \cdot 9 \mathrm{H}_{2} \mathrm{O}+\mathrm{Fe}\left(\mathrm{NO}_{3}\right)_{2} \cdot 9 \mathrm{H}_{2} \mathrm{O}+ \\
& \mathrm{Cd}\left(\mathrm{NO}_{3}\right)_{2} \cdot 6 \mathrm{H}_{2} \mathrm{O}+2 \mathrm{Na}_{2} \mathrm{WO}_{4}+\mathrm{NaOH} \\
& \rightarrow \mathrm{NH}_{4} \mathrm{NO}_{3}+\mathrm{NaNO}_{3}+\mathrm{Fe}_{3} \mathrm{O}_{4} / \mathrm{CdWO}_{4} / \mathrm{PrVO}_{4}+\mathrm{H}_{2} \mathrm{O}
\end{aligned}
$$

\subsection{Methods}

\subsubsection{Assessment of Photocatalytic Performance}

To identify the optimal sample, the photocatalytic performance of all the synthesized samples was assessed by $\mathrm{MB}$ photodegradation under visible light. In each experiment, $60 \mathrm{mg}$ of the dispersed photocatalyst was added to $300 \mathrm{~mL}$ of $25 \mathrm{ppm} \mathrm{MB}$ solution. Then, $1 \mathrm{~mL}$ of $25 \% \mathrm{H}_{2} \mathrm{O}_{2}$ was added to the photoreactor. Previous to exposure to the visible spectrum ( $250 \mathrm{~W}$ xenon lamp), the solution was stirred in darkness for $20 \mathrm{~min}$ to reach an adsorption/desorption equilibrium between the catalyst and the MB solution. Then, $4 \mathrm{~mL}$ of the solution was kept in darkness for $10 \mathrm{~min}$ and then for $20 \mathrm{~min}$ under the light. Next, the solutions were centrifuged at $5000 \mathrm{rpm}$ for $5 \mathrm{~min}$ to separate the catalysts. A UV-Vis spectrophotometer was used to determine the outcome of the photodegradation of MB. Finally, 
the photocatalytic activity of the $\mathrm{S} 4$ sample was determined via the photodegradation of $10 \mathrm{mg} / \mathrm{L}$ of $\mathrm{MO}$ and $10 \mathrm{mg} / \mathrm{L}$ of MV.

The photodegradation of MB under UV light was evaluated. In each experiment, $30 \mathrm{mg}$ of the photocatalyst was added to $300 \mathrm{~mL}$ of $20 \mathrm{mg} / \mathrm{L} \mathrm{MB}$ solution. Before irradiation under UV light (50 W $\mathrm{Hg}$ lamp), the solution was stirred in the dark for $20 \mathrm{~min}$ to get an adsorption/desorption equilibrium between the catalyst and the MB solution. Then, $4 \mathrm{~mL}$ of the solution was pipetted every $10 \mathrm{~min}$ and centrifuged at $5000 \mathrm{rpm}$ for $5 \mathrm{~min}$ to separate the catalyst. The concentration of MB solution was calculated via a UV-Vis spectrophotometer to identify the result of the photodegradation. Afterward, the optimized sample was used for the photodegradation of $15 \mathrm{mg} / \mathrm{L} \mathrm{MO}, 15 \mathrm{mg} / \mathrm{L} \mathrm{FNT}$, and $20 \mathrm{mg} / \mathrm{L}$ RhB via the same method.

\subsubsection{Photodegradation Mechanism}

Hydroxyl radicals $\left(\bullet^{\bullet} \mathrm{OH}\right)$ produced at the photocatalyst/water interface were analysed via terephthalic acid (TA) as a probe via a photoluminescence technique. A high fluorescence intensity of 2-hydroxyterephthalic acid is achieved by TA with ${ }^{\bullet} \mathrm{OH}$. Therefore, the intensity of fluorescence is directly proportional to the concentration of ${ }^{\bullet} \mathrm{OH}$. The experiments were similar to the photocatalytic testing under ultraviolet irradiation. The reaction was performed as follows: $0.03 \mathrm{~g}$ of photocatalyst $(0.1 \mathrm{~g} / \mathrm{L})$ was added into the $300 \mathrm{~mL}$ aqueous solution of terephthalic acid with a concentration of $0.0005 \mathrm{M}(0.451 \mathrm{~g}$ in $0.5 \mathrm{~L}$ distilled water) along with $0.002 \mathrm{M} \mathrm{NaOH}(0.04 \mathrm{~g}$ in $0.5 \mathrm{~L}$ distilled water). The principal oxidative species in the photocatalytic procedure were obtained, respectively, via the super oxide radical $\left({ }^{\bullet} \mathrm{O}^{2-}\right), \cdot \mathrm{OH}$, and holes, using benzoquinone, tert-butanol, and citric acid. First, $300 \mathrm{~mL}$ of $25 \mathrm{mg} / \mathrm{L} \mathrm{MB}$ and $3 \mathrm{mmol}$ from one of the scavengers was added to the solution. Next, $0.03 \mathrm{~g}$ of a dispersed photocatalyst was subjected to the ultraviolet irradiation. Finally, $4 \mathrm{~mL}$ of each solution was centrifuged, and the process was monitored through a UV-Vis spectrophotometer.

\subsubsection{Cell Culture}

PANC1 cell lines were prepared from the National Cell Bank of Iran (NCBI, Tehran). The cell line was grown in RPMI 1640 medium (Gibco) and supplemented with 10\% (v/v) FBS and penicillin/streptomycin (100 IU/mL and $100 \mu \mathrm{g} / \mathrm{mL}$, respectively). The cells were incubated and preserved at $37^{\circ} \mathrm{C}$ with $5 \% \mathrm{CO}_{2}$. As soon as confluence reached ca. $85 \%$, the cells were rinsed with pure RPMI and gathered using a $0.25 \%$ trypsin/EDTA solution. Each test was performed 3 times.

\subsubsection{MTT Assay}

An MTT assay was used to assess the cytotoxicity of the extract on the PANC1 cells. The potential of viable cells was determined via the production of a blue formazon catalyst from yellow tetrazolium salt through mitochondrial dehydrogenase. The cells were collected and plated in a 96-well plate (Nunc, Denmark) at a density of 104 cells/well and were treated with varying concentrations of nanoparticles $(2,1,0.5,0.25,0.125,0.063,0.0315$, and $0.0157 \mathrm{mg} / \mathrm{mL})$. For 1 and 2 days, the microplates were incubated at $37^{\circ} \mathrm{C}$ and $5 \% \mathrm{CO}_{2}$. Then, the supernatants were discarded, and $100 \mu \mathrm{L}$ of DMSO was added to each well and further incubated for $20 \mathrm{~min}$. The ELISA plate reader was used at $\lambda=570 \mathrm{~nm}$. The percentage of cell cytotoxicity and viability was achieved using the following relation [29]:

$$
\text { cytotoxicity }(\%)=1-\frac{\text { mean absorbance of toxicant }}{\text { mean absorbance of negative control }} \times 100 \text {. }
$$




\section{Results and Discussion}

\subsection{Characterization of Synthesized Nanostructures}

The X-ray diffraction (XRD) patterns of the powder materials of $\mathrm{Fe}_{3} \mathrm{O}_{4}, \mathrm{Fe}_{3} \mathrm{O}_{4} / \mathrm{CdWO}_{4}$ and the $\mathrm{Fe}_{3} \mathrm{O}_{4} / \mathrm{CdWO}_{4} / \mathrm{PrVO}_{4}$ sample (S4) are shown in Figure S1, and the main reflections are summarized in Table S1. As seen in Figure S1a, the $\mathrm{Fe}_{3} \mathrm{O}_{4}$ nanoparticles showed six peaks at the $2 \theta$ degrees of $30.0^{\circ}, 35.6^{\circ}, 42.9^{\circ}, 53.5^{\circ}, 56.9^{\circ}$ and $63.1^{\circ}$, which correspond to the cubic phases of $\mathrm{Fe}_{3} \mathrm{O}_{4}$ (JCPDS No. 01-075-0449) [50]. These peaks are related to the reflection of the X-rays from the (220), (311), (400), (411), (511), and (440) lattice planes, respectively. The average crystallite diameter (Dc), also calculated, was $14.1 \mathrm{~nm}$ (Table S1). The XRD pattern of $\mathrm{Fe}_{3} \mathrm{O}_{4} / \mathrm{CdWO}_{4}$ (Figure S1b) is composed of two pure phases of $\mathrm{Fe}_{3} \mathrm{O}_{4}$ (JCPDS No. 01-75-0449) and $\mathrm{CdWO}_{4}$ (JCPDS No. 01-084-1457) with diffraction peaks characteristic of the cubic phase of $\mathrm{Fe}_{3} \mathrm{O}_{4}$, as mentioned above, with additional peaks at $2 \theta=23.2^{\circ}, 29^{\circ}$, $35.2^{\circ}, 40^{\circ}, 47.5^{\circ}, 50.1^{\circ}, 50.3^{\circ}, 51.11^{\circ}$ and $60^{\circ}$, with the lines (110), (111), (002), (210), (112), (030), (022), (130) and (041), respectively. The Dc value was calculated as ca. $33.3 \mathrm{~nm}$ (Table S1). The XRD pattern of the $\mathrm{Fe}_{3} \mathrm{O}_{4} / \mathrm{CdWO}_{4} / \mathrm{PrVO}_{4}$ nanostructures consists of reflections from three phases of $\mathrm{Fe}_{3} \mathrm{O}_{4}$ (JCPDS No. 01-075-0449), $\mathrm{CdWO}_{4}$ (JCPDS No. 01-084-1457) and $\mathrm{PrVO}_{4}$ (JCPDS No. 084-1457) (Figure S1c). Figure S1c shows diffraction peaks at $24.03^{\circ}$ (line (200)), $32.04^{\circ}$ (line (112)), $40.1^{\circ}$ (line (231)), $47.86^{\circ}$ (line (322)) and $50.26^{\circ}$ (line (111)). The Dc value of the $\mathrm{Fe}_{3} \mathrm{O}_{4} / \mathrm{CdWO}_{4} / \mathrm{PrVO}_{4}$ nanostructures was evaluated, and it was ca. $55 \mathrm{~nm}$. The reflections from the $\mathrm{PrVO}_{4}$ planes are very low in intensity because of the small amount of this inorganic oxide present in the nanoparticles in comparison to other inorganic components. No other impurities or additional peaks were observed, which confirmed the high purity of the synthesized products.

As illustrated in Figure S2, the EDX spectrum of the $\mathrm{Fe}_{3} \mathrm{O}_{4} / \mathrm{CdWO}_{4} / \mathrm{PrVO}_{4}$ (sample S4) nanoparticles is made up of six varied elements, Fe, O, Cd, W, Pr, and V. Furthermore, no impurity peaks were found, indicating that the $\mathrm{Fe}_{3} \mathrm{O}_{4} / \mathrm{CdWO}_{4} / \mathrm{PrVO}_{4}$ nanoparticles have a high purity.

The surface morphologies of the $\mathrm{Fe}_{3} \mathrm{O}_{4} / \mathrm{CdWO}_{4}$ and $\mathrm{Fe}_{3} \mathrm{O}_{4} / \mathrm{CdWO}_{4} / \mathrm{PrVO}_{4}$ nanoparticles (samples S1 and S4) were studied using scanning electron microscopy (SEM). The structures of S1 and S4 exhibit porous morphologies, with numerous channels and outcroppings (Figure 1a,b). All of the samples are composed of aggregates of the nanoparticles with sizes under $100 \mathrm{~nm}$. The $\mathrm{Fe}_{3} \mathrm{O}_{4} / \mathrm{CdWO}_{4}$ nanoparticles formed aggregates with an average size of $60-70 \mathrm{~nm}$ (Figure 1c). The $\mathrm{S} 4$ sample shows a uniform morphology with larger crystallites in the range of 90-100 $\mathrm{nm}$ (Figure 1d). In addition, the outcomes proved that the particle size obtained by SEM is larger than that obtained by XRD. This refers to the point where the SEM images show the aggregates of many inorganic crystallites.

The particle sizes of the synthesized nanoparticles were also estimated from the high-resolution transmission electron microscopy (HRTEM) (Figure 1e,f). All of the HRTEM images show spherical $\mathrm{Fe}_{3} \mathrm{O}_{4} / \mathrm{CdWO}_{4}$ and $\mathrm{Fe}_{3} \mathrm{O}_{4} / \mathrm{CdWO}_{4} / \mathrm{PrVO}_{4}$ nanoparticles with mean particle sizes of 20-30 (Figure 1e) and 50-55 nm (Figure 1f), respectively. The $\mathrm{PrVO}_{4}$ coating of the $\mathrm{Fe}_{3} \mathrm{O}_{4} / \mathrm{CdWO}_{4}$ process leads to the formation of some polygonal and spherical nanostructures with different diameters (Figure 1f).

In Figure 2, the magnetic behaviour of the nanosized structures was verified via the hysteric curve at $300 \mathrm{~K}$ and the nearly saturated nature. The results showed the magnetic contribution of the as-fabricated $\mathrm{Fe}_{3} \mathrm{O}_{4} / \mathrm{CdWO}_{4} / \mathrm{PrVO}_{4}$ nanoparticles at room temperature. Furthermore, the VSM data validated that the as-fabricated products could be classified as paramagnetic nanomaterials, and their magnetization values were approximately 51 and $0.13 \mathrm{emu} / \mathrm{g}$ for the $\mathrm{Fe}_{3} \mathrm{O}_{4}$ and $\mathrm{Fe}_{3} \mathrm{O}_{4} / \mathrm{CdWO}_{4} / \mathrm{PrVO}_{4}$ nanoparticles at room temperature, respectively. 

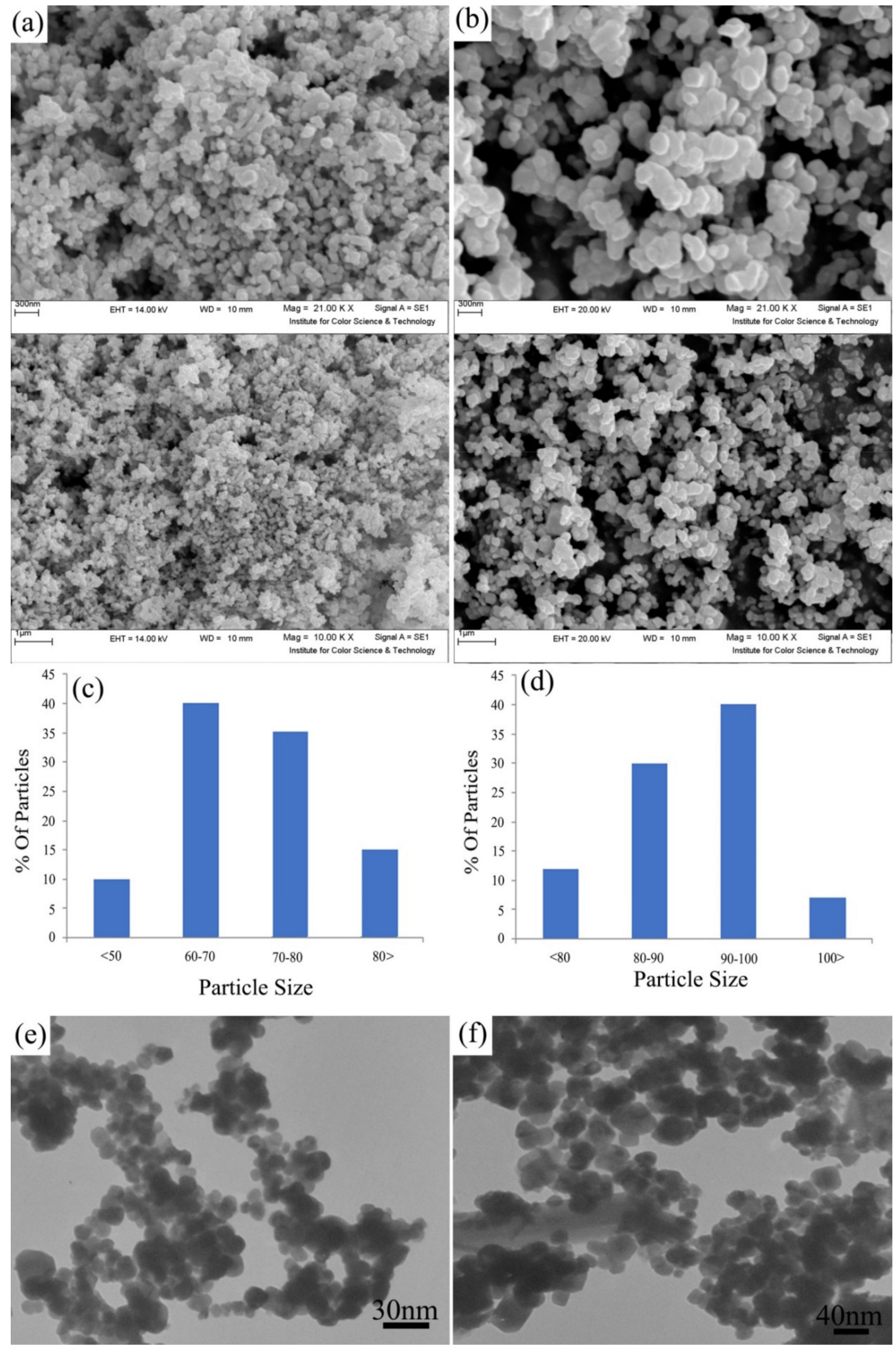

Figure 1. (a,b) The SEM images, $(\mathbf{c}, \mathbf{d})$ particle size distribution and $(\mathbf{e}, \mathbf{f})$ HRTEM images of the $(\mathbf{a}, \mathbf{c}, \mathbf{e})$ $\mathrm{Fe}_{3} \mathrm{O}_{4} / \mathrm{CdWO}_{4}$ (S1) and (b,d,f) $\mathrm{Fe}_{3} \mathrm{O}_{4} / \mathrm{CdWO}_{4} / \mathrm{PrVO}_{4}$ (S4) samples. 
(a)

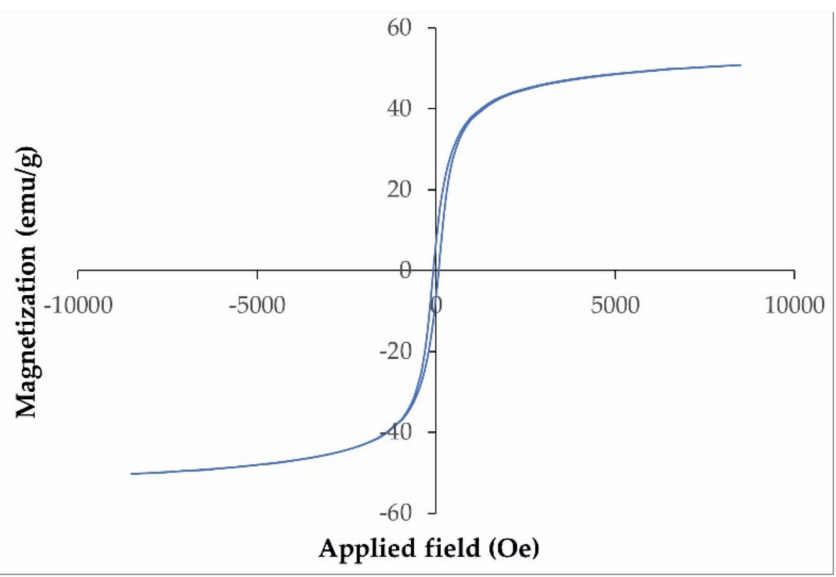

(b)

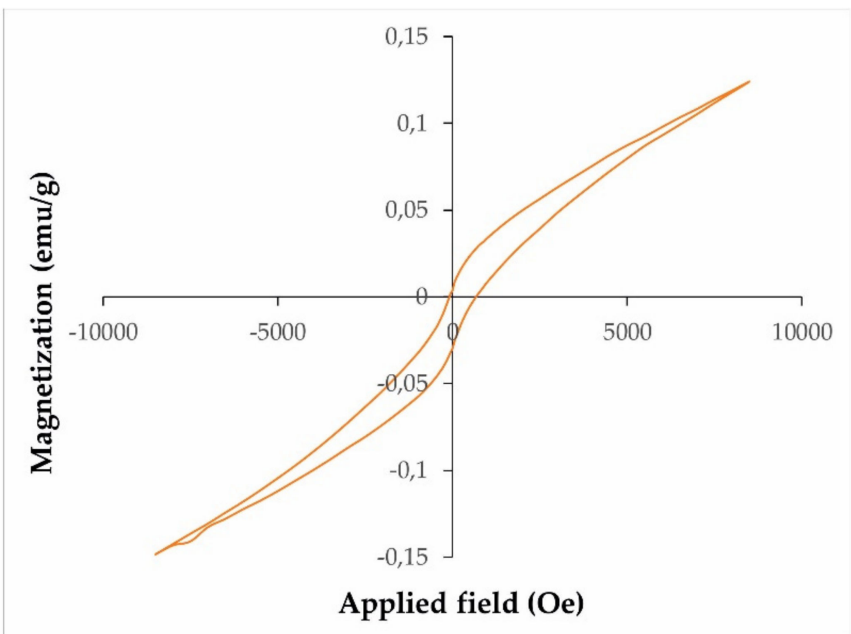

Figure 2. The magnetic hysteresis loops of the (a) $\mathrm{Fe}_{3} \mathrm{O}_{4}$ and (b) $\mathrm{Fe}_{3} \mathrm{O}_{4} / \mathrm{CdWO}_{4} / \mathrm{PrVO}_{4}$ (S4) samples.

The band gap energies of the prepared nanoparticles were examined via UV-Vis absorption spectroscopy, as shown in Figure 3. From the UV-Vis spectra (Figure 3a), the band gap was found by extrapolating the steepest portion of the $(\alpha \mathrm{h} v)^{1 / 2}$ vs. hv plot by using Tauc's formula:

$$
\alpha h v=A\left(h v-E_{g}\right)^{\eta} .
$$

Tauc's plots were made for the $\mathrm{Fe}_{3} \mathrm{O}_{4} / \mathrm{CdWO}_{4}$ (S1) and $\mathrm{Fe}_{3} \mathrm{O}_{4} / \mathrm{CdWO}_{4} / \mathrm{PrVO}_{4}$ (S4) samples gaps of the material (Figure 3b). Using Equation (14), the energy gaps were calculated for the S1 and S4 samples and were determined to be 3.1 and $2.8 \mathrm{eV}$, respectively.

To identify the functional groups and oxide metal bonding in $\mathrm{Fe}_{3} \mathrm{O}_{4}, \mathrm{Fe}_{3} \mathrm{O}_{4} / \mathrm{CdWO}_{4}$ (sample S1) and $\mathrm{Fe}_{3} \mathrm{O}_{4} / \mathrm{CdWO}_{4} / \mathrm{PrVO}_{4}$ (sample S4) before and after the calcination process, and after photocatalysis in the presence of the MB dye, Fourier transformation infrared (FT-IR) spectroscopy was used; the results are presented in Figure 4. The FT-IR spectra were recorded between the $450 \mathrm{~cm}^{-1}$ and $3500 \mathrm{~cm}^{-1}$ wavelengths at room temperature. 

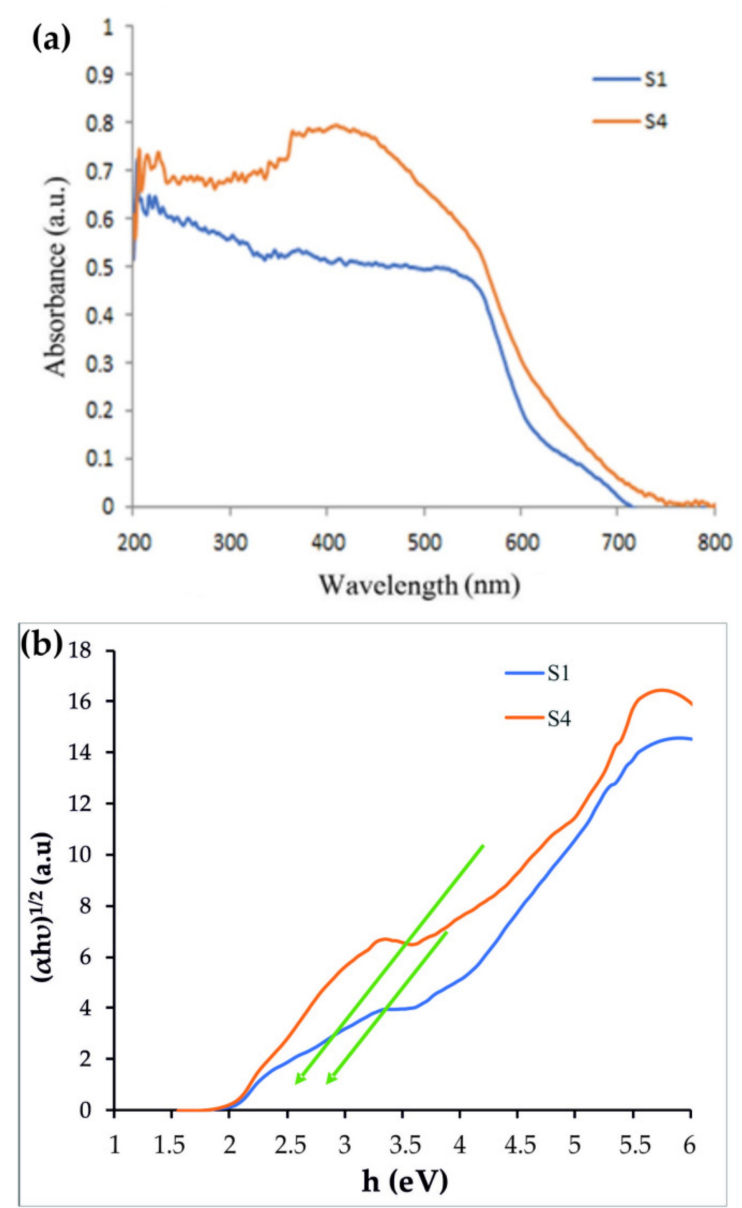

Figure 3. The (a) UV-vis absorbance spectra and (b) Tauc's plots for the $\mathrm{Fe}_{3} \mathrm{O}_{4} / \mathrm{CdWO}_{4}(\mathrm{~S} 1$ ) and $\mathrm{Fe}_{3} \mathrm{O}_{4} / \mathrm{CdWO}_{4} / \mathrm{PrVO}_{4}(\mathrm{~S} 4)$ samples.

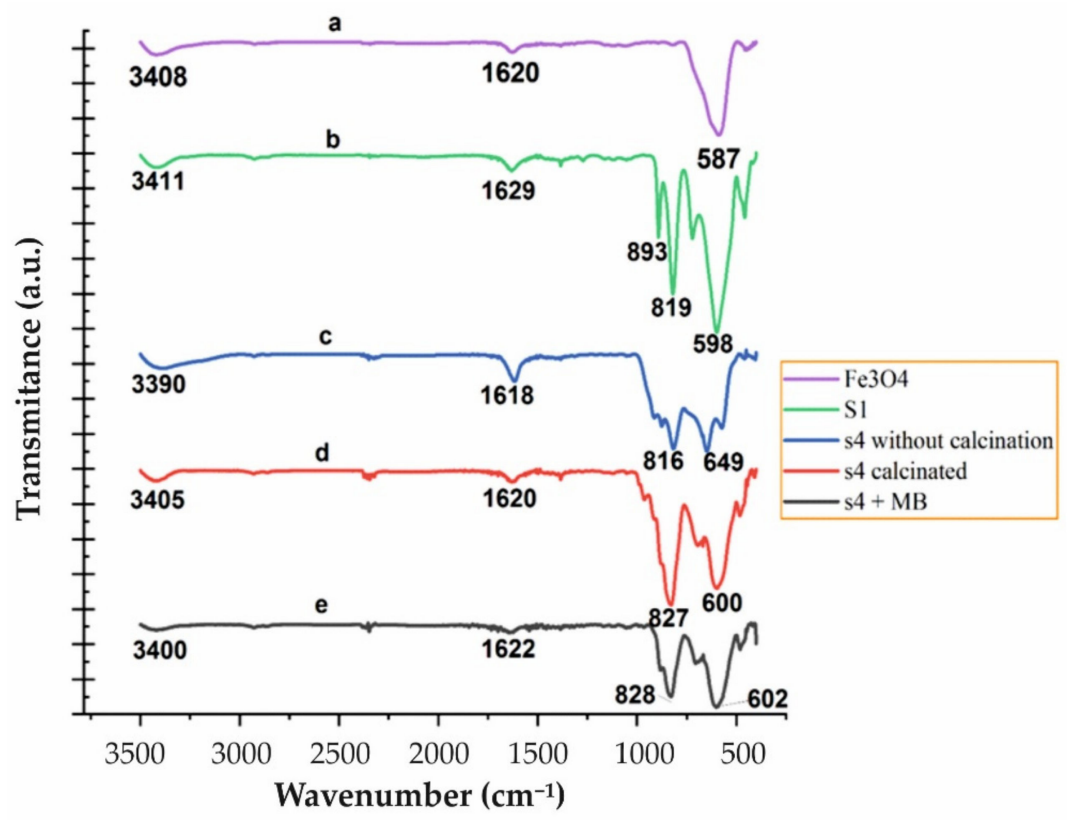

Figure 4. The FTIR spectra of (a) $\mathrm{Fe}_{3} \mathrm{O}_{4}$, (b) $\mathrm{Fe}_{3} \mathrm{O}_{4} / \mathrm{CdWO}_{4}$ (S1), and (c) $\mathrm{Fe}_{3} \mathrm{O}_{4} / \mathrm{CdWO}_{4} / \mathrm{PrVO}_{4}$ (S4) before calcination, (d) $\mathrm{Fe}_{3} \mathrm{O}_{4} / \mathrm{CdWO}_{4} / \mathrm{PrVO}_{4}$ (S4) after calcination, and (e) $\mathrm{Fe}_{3} \mathrm{O}_{4} / \mathrm{CdWO}_{4} / \mathrm{PrVO}_{4}$ (S4) after a period of $\mathrm{MB}$ photodegradation. 
The absorption bands in the range of $1618-1629 \mathrm{~cm}^{-1}$ and $3390-3410 \mathrm{~cm}^{-1}$, observed for all spectra, are assigned to the deformation vibration of the $\mathrm{H}-\mathrm{O}-\mathrm{H}$ bonds and to the stretching vibration of the $\mathrm{O}-\mathrm{H}$ bonds [35], respectively (Figure 4). The absorption band at $587 \mathrm{~cm}^{-1}$ is related to the $\mathrm{Fe}-\mathrm{O}$ vibration (Figure 4a) [51]. Some additional absorption bands at 455, 716, 819, and $893 \mathrm{~cm}^{-1}$ were observed for the $\mathrm{CdWO}_{4}$ nanostructures, and they are attributed to the vibration modes present in these nanoparticles after the absorption of the infrared wavelength (Figure $4 \mathrm{~b}$ ). The peak at $455 \mathrm{~cm}^{-1}$ may be attributed to the $\mathrm{Cd}-\mathrm{O}$ stretching vibration mode, whereas the peaks at 716 and $819 \mathrm{~cm}^{-1}$ were due to $\mathrm{O}-\mathrm{W}-\mathrm{O}$, and the peak at $820 \mathrm{~cm}^{-1}$ was due to $\mathrm{Cd}-\mathrm{O}-\mathrm{W}[36,37,52,53]$. The FT-IR spectra confirm the presence of stretching and bending vibrations of metal cations, such as the $\mathrm{Cd}-\mathrm{O}, \mathrm{O}-\mathrm{W}-\mathrm{O}$ and $\mathrm{Cd}-\mathrm{O}-\mathrm{W}$ bands in the $\mathrm{CdWO}_{4}$ structure.

Figure $4 \mathrm{c}$, d shows the FT-IR spectra of the $\mathrm{S} 4$ sample before and after calcination, respectively. The peak at $816 \mathrm{~cm}^{-1}$ (Figure 4c), which was replaced by $827 \mathrm{~cm}^{-1}$ (Figure $4 \mathrm{~d}$ ), is related to the calcination process. The peak became more intense and may be related to the vibrational modes of the $\mathrm{V}-\mathrm{O}$ bond. The small absorption peak at $451 \mathrm{~cm}^{-1}$ belongs to the $\mathrm{Pr}-\mathrm{O}$ vibration frequency [54]. Figure 6e shows the FT-IR spectra of the S4 sample after the photodegradation of MB by UV light irradiation. No change in the absorption spectra of the inorganic nanoparticles was observed, which indicates that these nanoparticles are stable and were not destroyed during the photocatalytic reactions.

\subsection{Photocatalytic Performance}

The photocatalytic properties of the synthesized samples, assisted by $100 \mathrm{~mL} \mathrm{MB}$ in $1 \mathrm{~mL} \mathrm{H}_{2} \mathrm{O}_{2}$, under visible light irradiation, were tested to find the nanoparticles with the highest photocatalytic performance. The efficiency of $\mathrm{H}_{2} \mathrm{O}_{2}$, a non-catalytic pollutant photodegradation, was also studied with and without light to evaluate the photocatalytic properties of the synthesized nanoparticles. The results are shown in Figure 5a. Additionally, the kinetics of the photocatalytic processes in terms of the irradiation time were determined $\left(-\ln \left(C / C_{0}\right)\right)$. The mathematical analysis is presented in Figure $5 b$. The slope of the linear regression was utilized as the first-order reaction rate constant. A comparison of all samples clearly showed (Figure 5) that the higher photocatalytic activity was performed by $\mathrm{S} 4$ $\left(\mathrm{Fe}_{3} \mathrm{O}_{4} / \mathrm{CdWO}_{4} / \mathrm{PrVO}_{4}\right)$. S4 has a good potential to eliminate all organic contaminants.

Similar experiments on the photodegradation of MV and MO were performed with the same sample (S4), and the results are displayed in Figure 6. Some additional photocatalytic degradation tests were carried out using $\mathrm{MB}, \mathrm{MO}, \mathrm{FNT}$, and $\mathrm{RhB}$ pollutants to gain a better understanding of the $S 4$ properties under an ultraviolet wavelength, and the results are shown in Figure 7 . Therefore, the reduced size of sample S4 led to an increase in the surface of the nanoparticles as well as more absorption under ultraviolet rays, improving the production of the radical species and resulting in the enhancement of the degradation of dyes.

The photocatalytic degradation of pollutants occurs via the reactive sample, after the light absorption and the electron-hole formation by the photocatalyst [55]. The terephthalic acid (TA) photoluminescence technique was used to study the generation of active ${ }^{\bullet} \mathrm{OH}$ radicals for all samples, as summarized in Table S2 [38]. By means of ${ }^{\bullet} \mathrm{OH}$ by TA, 2-hydroxyl-TA could be formed. This has a high fluorescence radiation, and as a result the ${ }^{\bullet} \mathrm{OH}$ could be monitored incidentally once we monitored the changes in the fluorescence intensity of the TA solution. The change in the fluorescence intensity of 2-hydroxyl-TA is shown in Figure S3. Therefore, any increase in ${ }^{\bullet} \mathrm{OH}$ can lead to an increase in 2-hydroxyl-TA, which has a fluorescence property. Hence, the production of ${ }^{\bullet} \mathrm{OH}$ radicals will be improved, and as a result, the degradation of the dyes will be enhanced. 
(a)

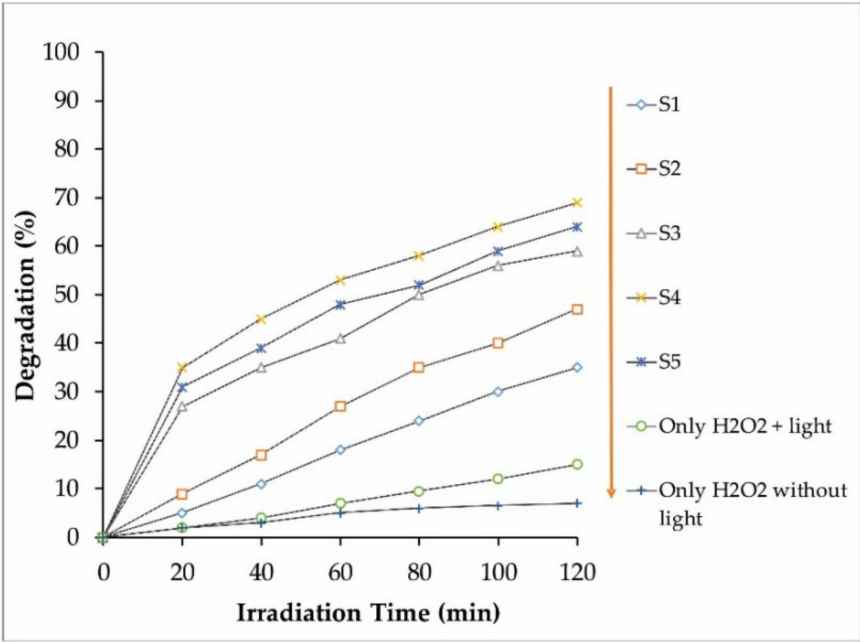

(b)

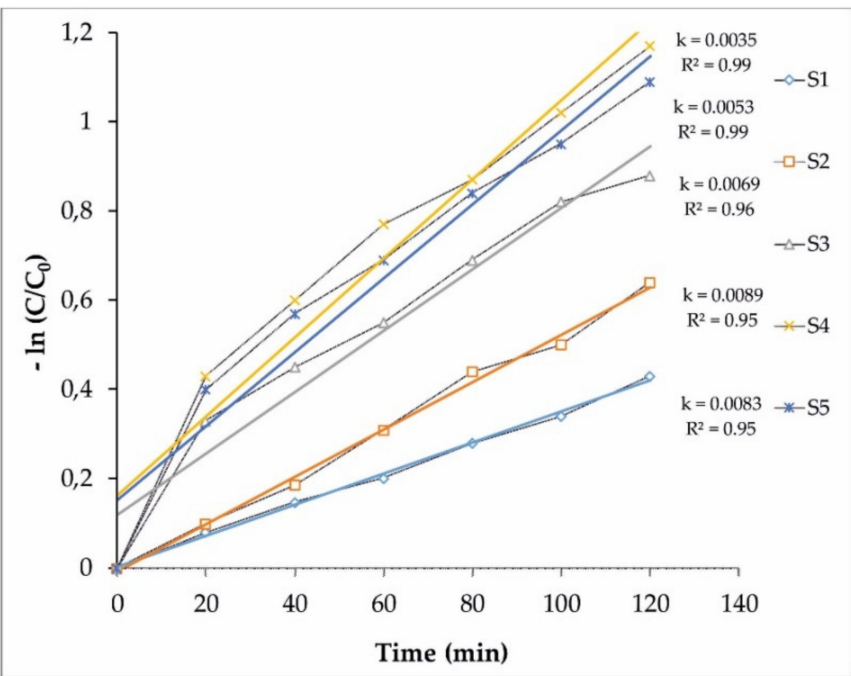

Figure 5. (a) The photocatalytic degradation of MB (S1-S5 samples) under visible light assisted by $\mathrm{H}_{2} \mathrm{O}_{2}$. (b) The pseudo-first-order kinetics of the MB degradation for S1-S5 samples.

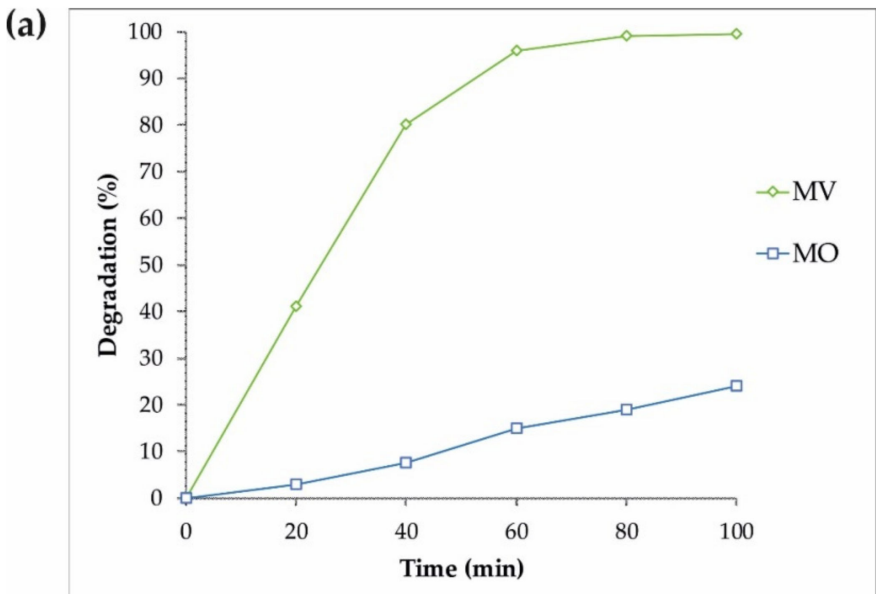

Figure 6. Cont. 
(b)

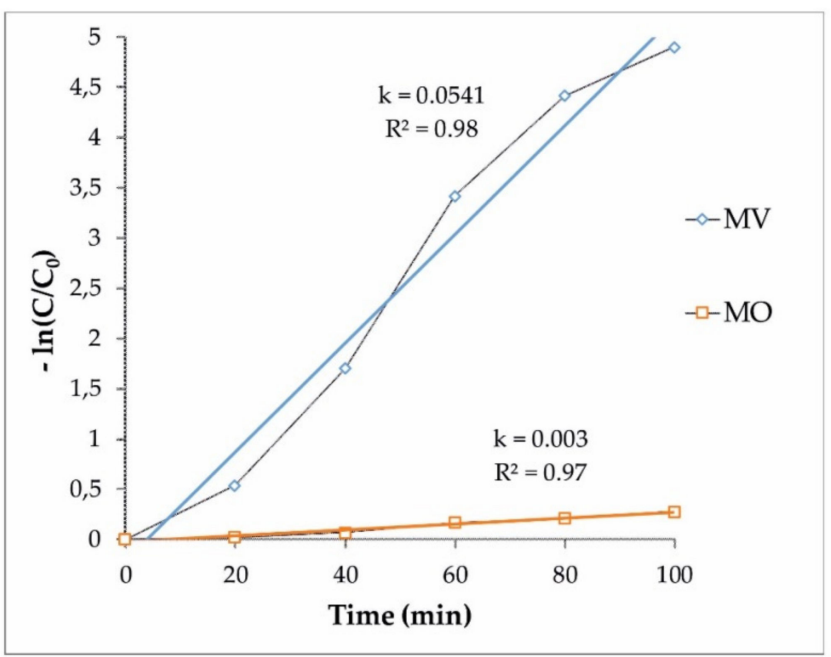

Figure 6. (a) The photocatalytic degradation of the MV and MO pollutants by the S4 sample under visible light assisted by $\mathrm{H}_{2} \mathrm{O}_{2}$, and (b) the pseudo-first-order kinetics of the MV and MO degradation by S4.

(a)

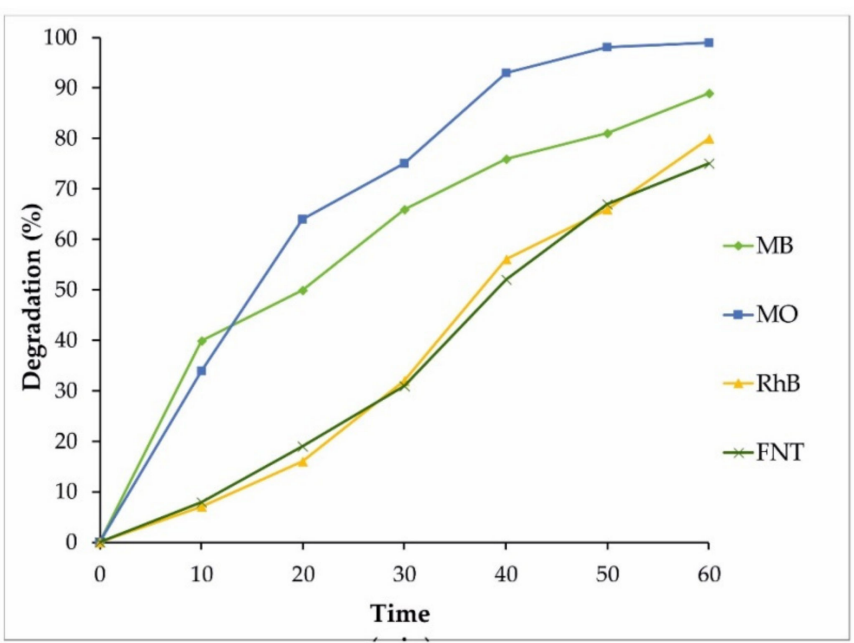

(b)

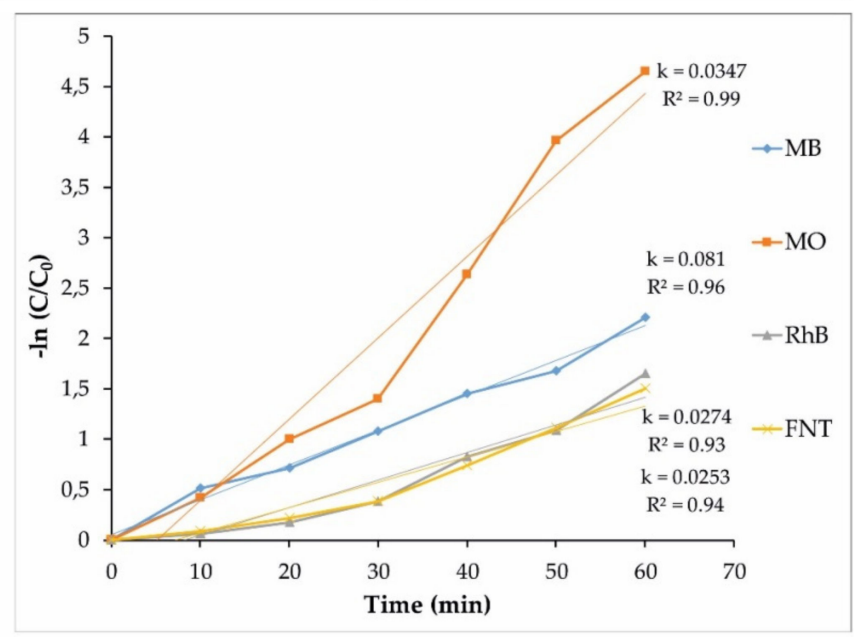

Figure 7. (a) The photocatalytic degradation of $\mathrm{MB}, \mathrm{MO}, \mathrm{RhB}$, and FNT by the $\mathrm{S} 4$ sample under UV light irradiation. (b) The pseudo-first-order kinetics of the MB, MO, FNT, and RhB degradation by the S4 sample. 
As shown in Figure S3, the UV irradiation time is directly proportional to the fluorescence intensity. However, the intensity of ${ }^{\bullet} \mathrm{OH}$ reaches its minimum value during the first $10 \mathrm{~min}$ in the absence of irradiation. This indicates the formation of ${ }^{\bullet} \mathrm{OH}$ all over the photocatalyst with ultraviolet waves. Due to the factors described in the absence of UV light, we obtained a minimal amount of ${ }^{\bullet} \mathrm{OH}$. Conversely, in the presence of UV light, the fluorescence was intensified; this was interpreted as a larger production of ${ }^{\bullet} \mathrm{OH}$, which led to an increase in the degradation of the dyes.

Trapping tests of holes $(\mathrm{h}+)$ were used to establish the principal oxidative samples via superoxide radical $\left(\mathrm{O}_{2}{ }^{\bullet-}\right)$ and ${ }^{\bullet} \mathrm{OH}$, citric acid, benzoquinone, as well as tert-butanol [10]. As shown in the picture, citric acid can remove holes $(\mathrm{h}+)$ in the solution, which results in the degradation of the dyes by up to $92 \%$. Therefore, holes $(\mathrm{h}+)$ have no significant effect on the solution. However, without $\mathrm{O}_{2}{ }^{--}$or - $\mathrm{OH}$, the degradation of the dyes was observed at levels of $35 \%$ and $76 \%$, respectively. These findings suggest that both radicals $\left(\mathrm{O}_{2}{ }^{\bullet-}\right.$ and $\left.{ }^{\bullet} \mathrm{OH}\right)$ could be considered to be important reactive species in the photocatalytic destruction reaction of $\mathrm{MB}$ in the presence of $\mathrm{Fe}_{3} \mathrm{O}_{4} / \mathrm{CdWO}_{4} / \mathrm{PrVO}_{4}$.

$$
\begin{gathered}
\mathrm{Fe}_{3} \mathrm{O}_{4} / \mathrm{CdWO}_{4} / \mathrm{PrVO}_{4}+\mathrm{h} v \rightarrow \mathrm{Fe}_{3} \mathrm{O}_{4} / \mathrm{CdWO}_{4} / \mathrm{PrVO}_{4}{ }^{\bullet}+\mathrm{e}^{-}+\mathrm{h}^{+} \\
\mathrm{e}^{-}+\mathrm{O}_{2} \rightarrow \mathrm{O}_{2}^{\bullet-} \\
\mathrm{O}_{2}^{\bullet-}+\mathrm{H}_{2} \mathrm{O} \rightarrow \mathrm{OOH}^{\bullet}+\mathrm{OH}^{-} \\
\mathrm{OOH}^{\bullet} \rightarrow \mathrm{O}_{2}+\mathrm{H}_{2} \mathrm{O}_{2} \\
\mathrm{H}_{2} \mathrm{O}_{2}+\mathrm{O}_{2}^{\bullet-} \rightarrow \mathrm{OOH}^{\bullet}+\mathrm{OH}^{-}+\mathrm{O}_{2} \\
\mathrm{OH}^{\bullet}+\mathrm{MB} \rightarrow \text { destruction products } \\
\mathrm{O}_{2}^{\bullet-}+\mathrm{MB} \rightarrow \text { destruction products }
\end{gathered}
$$

The outcomes of applying these scavengers for the photodegradation of $\mathrm{MB}$ (25 ppm) are represented in Figure 8. The addition of a superoxide scavenger to the studied solution could lead to a reduction of the photocatalytic performance of inorganic nanoparticles by up to two thirds. Interestingly, the addition of a hydroxyl scavenger resulted in a noticeable decrease in the photocatalytic performance (less than half). However, the addition of a holes scavenger had an insubstantial influence on the photocatalytic activity of the inorganic nanoparticles.

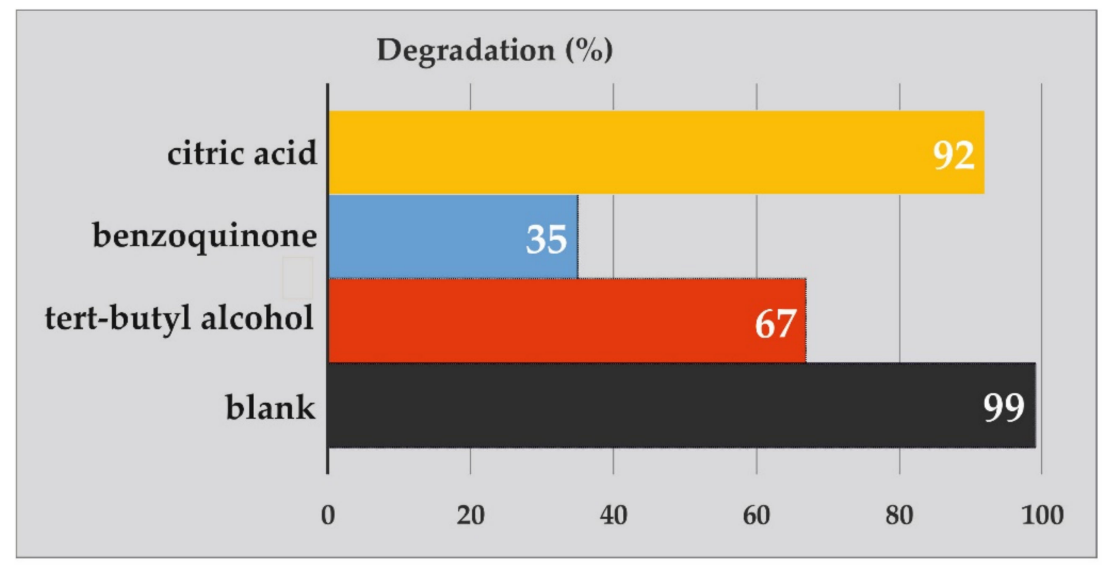

Figure 8. The effect of different scavengers (benzoquinone, tert-butyl alcohol and citric acid) on the photocatalytic degradation of MB.

\subsection{Cytotoxicity Effect on PANC1 Cells}

The MTT assay shows that the S4 nanocomposite had a toxic effect on a PANC1 cell line in a dose-depended manner, and its IC50 was approximately $125 \mathrm{mg} / \mathrm{L}$ (Figure 9). Additionally, Figure S4 presents the microscopic photos of PANC1 cells with S4 at the three different concentrations. The 
presented studies confirmed that the toxicity of the $\mathrm{S} 4$ sample was reduced by reducing its concentration. The in vitro studies indicated that the $\mathrm{Fe}_{3} \mathrm{O}_{4} / \mathrm{CdWO}_{4} / \mathrm{PrVO}_{4}$ nanoparticles were able to inhibit the growth of the PANC1 cancer cells. Therefore, these inorganic nanoparticles have some potential to be developed as new and novel anticancer agents for the treatment of pancreatic cancer based on the outcome provided as primary evidence [56].

(a)

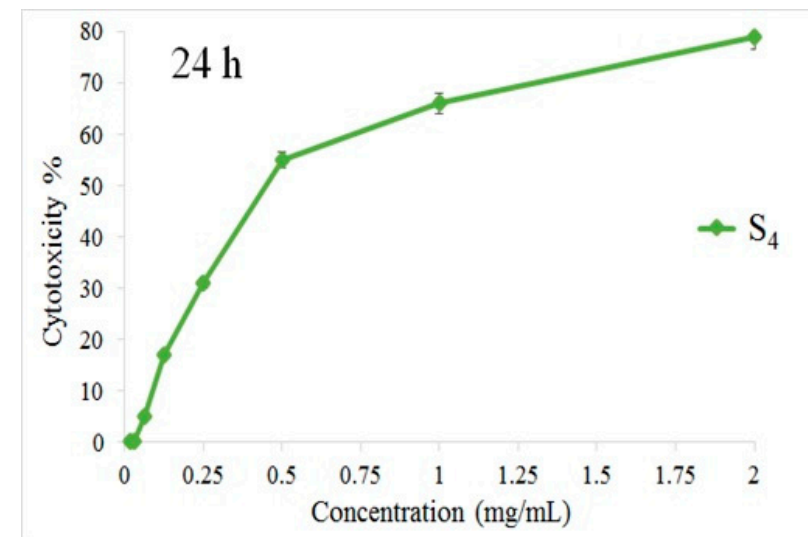

(b)

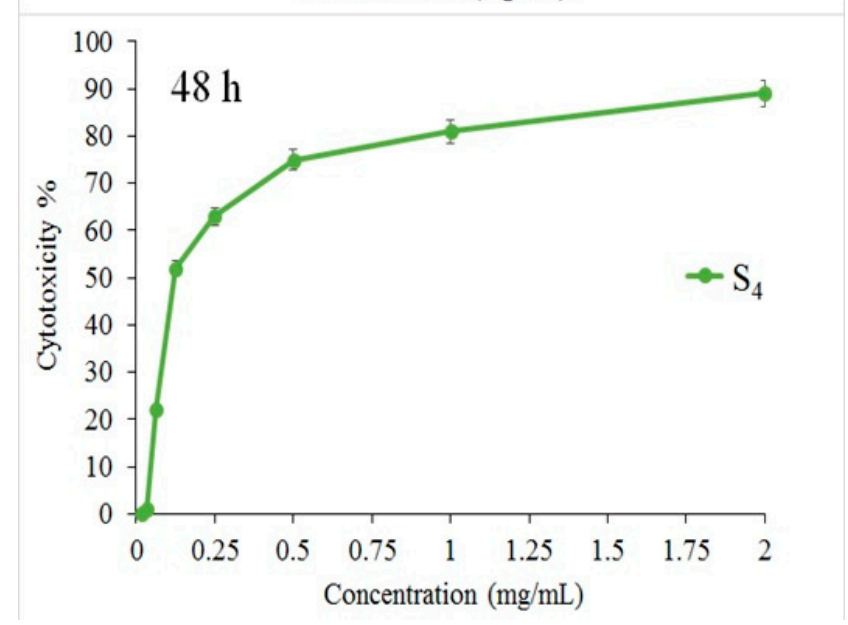

Figure 9. The relative in vitro cell viability of optimized $\mathrm{Fe}_{3} \mathrm{O}_{4} / \mathrm{CdWO}_{4} / \mathrm{PrVO}_{4}$ (MTT assay). PANC1 cells incubated with $\mathrm{Fe}_{3} \mathrm{O}_{4} / \mathrm{CdWO}_{4} / \mathrm{PrVO}_{4}$ for (a) $24 \mathrm{~h}$ and (b) $48 \mathrm{~h}$.

\section{Conclusions}

In summary, magnetic $\mathrm{Fe}_{3} \mathrm{O}_{4} / \mathrm{CdWO}_{4}$ and $\mathrm{Fe}_{3} \mathrm{O}_{4} / \mathrm{CdWO}_{4} / \mathrm{PrVO}_{4}$ nanostructures were prepared at various molar ratios of inorganic salts via the co-precipitation method assisted by the ultrasonic technique. XRD, EDS, SEM, and FTIR methods established the presence of the desired nanoparticles with different transition metals. The DRS data showed an important reduction in the band gap when adding $\mathrm{PrVO}_{4}$ to the "core" phases $\left(\mathrm{Fe}_{3} \mathrm{O}_{4}\right.$ and $\left.\mathrm{CdWO}_{4}\right)$. The DRS test showed that the OBGEs of $\mathrm{Fe}_{3} \mathrm{O}_{4}$ and the $\mathrm{S} 4$ sample were 3.1 and $2.8 \mathrm{eV}$, respectively. The VSM test determined the MS values of $\mathrm{Fe}_{3} \mathrm{O}_{4}$ and $\mathrm{S} 4$, which were 50.9 and $0.13 \mathrm{emu} / \mathrm{g}$, respectively. The highest photocatalytic activity was shown by $\mathrm{Fe}_{3} \mathrm{O}_{4} / \mathrm{CdWO}_{4} / \mathrm{PrVO}_{4}$, with a ratio of 1:2:1 (S4). The degradation of $\mathrm{MB}$ with a $70 \%$ yield under visible light was observed. This sample was also used for the photodegradation of $\mathrm{MO}$, MV, FNT, and RhB under visible and UV light. The IC50 of the S4 sample on a PANC1 cell line was approximately $125 \mathrm{mg} / \mathrm{L}$, as determined by the MTT assay.

Supplementary Materials: The following are available online at http://www.mdpi.com/1996-1944/12/19/3274/s1, Figure S1: XRD patterns of (a) $\mathrm{Fe}_{3} \mathrm{O}_{4}$, (b) $\mathrm{Fe}_{3} \mathrm{O}_{4} / \mathrm{CdWO}_{4}$ (S1), and (c) $\mathrm{Fe}_{3} \mathrm{O}_{4} / \mathrm{CdWO}_{4} / \mathrm{PrVO}_{4}$ (S4); Table S1: Main reflections in the XRD patterns of inorganic nanoparticles; Figure S2: The EDX spectrum of the Fe3O4/CdWO4/PrVO4 (S4) sample; Figure S3: The temporal changes in fluorescence intensity under UV 
light (290 nm) irradiation for S4; Figure S4: The relative in vitro cell viability of optimized $\mathrm{Fe}_{3} \mathrm{O}_{4} / \mathrm{CdWO}_{4} / \mathrm{PrVO}_{4}$ (MTT assay). PANC1 cells incubated with $\mathrm{Fe}_{3} \mathrm{O}_{4} / \mathrm{CdWO}_{4} / \mathrm{PrVO}_{4}$ for (a) $24 \mathrm{~h}$ and (b) $48 \mathrm{~h}$.

Author Contributions: Conceptualization, M.A.M., M.R.N. and A.S.N.; statistical analysis, M.A.M., M.R.N. and A.S.N.; writing-original draft preparation, M.A.M, M.R.N., A.S.N., M.F.-R., K.A., S.P., F.A., and M.R.G.; methodology; writing - review and editing, M.E.P.-B.; funding acquisition, M.R.N., and M.E.P.-B. All authors approved the final version for submission.

Funding: We gratefully acknowledge the financial support from Iran University of Medical Sciences to M.R.N. and from the Ministry of Science and Higher Education, Poland (SUB/2/DN/19/001/2204) to M.E.P.-B.

Conflicts of Interest: The authors declare no conflicts of interest.

\section{References}

1. Gutierrez, A.M.; Dziubla, T.D.; Hilt, J.Z. Recent Advances on Iron Oxide Magnetic Nanoparticles as Sorbents of Organic Pollutants in Water and Wastewater Treatment. Rev. Environ. Health 2017, 32, 111-117. [CrossRef] [PubMed]

2. Oleshkevich, E.; Teixidor, F.; Rosell, A.; Viñas, C. Merging Icosahedral Boron Clusters and Magnetic Nanoparticles: Aiming toward Multifunctional Nanohybrid Materials. Inorg. Chem. 2018, 57, 462-470. [CrossRef] [PubMed]

3. Ramachandran, R.; Jung, D.; Bernier, N.A.; Logan, J.K.; Waddington, M.A.; Spokoyny, A.M. Sonochemical Synthesis of Small Boron Oxide Nanoparticles. Inorg. Chem. 2018, 57, 8037-8041. [CrossRef] [PubMed]

4. Ghosh, T.; Cho, K.-Y.; Ullah, K.; Nikam, V.; Park, C.-Y.; Meng, Z.-D.; Oh, W.-C. High Photonic Effect of Organic Dye Degradation by CdSe-Graphene-TiO2 Particles. J. Ind. Eng. Chem. 2013, 19, 797-805. [CrossRef]

5. Tripathy, N.; Ahmad, R.; Kuk, H.; Lee, D.H.; Hahn, Y.-B.; Khang, G. Rapid Methyl Orange Degradation Using Porous ZnO Spheres Photocatalyst. J. Photochem. Photobiol. B Biol. 2016, 161, 312-317. [CrossRef] [PubMed]

6. Zhang, R.; Cai, Y.; Zhu, X.; Han, Q.; Zhang, T.; Liu, Y.; Li, Y.; Wang, A. A Novel Photocatalytic Membrane Decorated with PDA/RGO/Ag3PO4 for Catalytic Dye Decomposition. Colloids Surf. A Physicochem. Eng. Asp. 2019, 563, 68-76. [CrossRef]

7. Peymani-Motlagh, S.M.; Sobhani-Nasab, A.; Rostami, M.; Sobati, H.; Eghbali-Arani, M.; Fasihi-Ramandi, M.; Ganjali, M.R.; Rahimi-Nasrabadi, M. Assessing the Magnetic, Cytotoxic and Photocatalytic Influence of Incorporating Yb3+ or Pr3+ Ions in Cobalt-Nickel Ferrite. J. Mater. Sci. Mater. Electron. 2019, 30, 6902-6909. [CrossRef]

8. Rahimi-Nasrabadi, M.; Pourmortazavi, S.M.; Ganjali, M.R.; Norouzi, P.; Faridbod, F.; Karimi, M.S. Statistically Optimized Synthesis of Dyspersium Tungstate Nanoparticles as Photocatalyst. J. Mater. Sci. Mater. Electron. 2016, 27, 12860-12868. [CrossRef]

9. Hosseinpour-Mashkani, S.M.; Sobhani-Nasab, A. A Simple Sonochemical Synthesis and Characterization of CdWO4 Nanoparticles and Its Photocatalytic Application. J. Mater. Sci. Mater. Electron. 2016, 27, 3240-3244. [CrossRef]

10. Rahimi-Nasrabadi, M.; Pourmortazavi, S.M.; Aghazadeh, M.; Ganjali, M.R.; Karimi, M.S.; Novrouzi, P. Optimizing the Procedure for the Synthesis of Nanoscale Gadolinium(III) Tungstate as Efficient Photocatalyst. J. Mater. Sci. Mater. Electron. 2017, 28, 3780-3788. [CrossRef]

11. Sobhani-Nasab, A.; Rangraz-Jeddy, M.; Avanes, A.; Salavati-Niasari, M. Novel Sol-Gel Method for Synthesis of PbTiO3 and Its Light Harvesting Applications. J. Mater. Sci. Mater. Electron. 2015, 26, 9552-9560. [CrossRef]

12. Ahmadi, F.; Rahimi-Nasrabadi, M.; Behpour, M. Synthesis Nd2TiO5 Nanoparticles with Different Morphologies by Novel Approach and Its Photocatalyst Application. J. Mater. Sci. Mater. Electron. 2017, 28, 1531-1536. [CrossRef]

13. Salavati-Niasari, M.; Soofivand, F.; Sobhani-Nasab, A.; Shakouri-Arani, M.; Hamadanian, M.; Bagheri, S. Facile Synthesis and Characterization of CdTiO3 Nanoparticles by Pechini Sol-Gel Method. J. Mater. Sci. Mater. Electron. 2017, 28, 14965-14973. [CrossRef]

14. Rostami, M.; Rahimi-Nasrabadi, M.; Ganjali, M.R.; Ahmadi, F.; Shojaei, A.F.; Delavar Rafiee, M. Facile Synthesis and Characterization of TiO2-Graphene-ZnFe2-x Tb x O4 Ternary Nano-Hybrids. J. Mater. Sci. 2017, 52, 7008-7016. [CrossRef] 
15. Eghbali-Arani, M.; Sobhani-Nasab, A.; Rahimi-Nasrabadi, M.; Pourmasoud, S. Green Synthesis and Characterization of SmVO4 Nanoparticles in the Presence of Carbohydrates As Capping Agents with Investigation of Visible-Light Photocatalytic Properties. J. Electron. Mater. 2018, 47, 3757-3769. [CrossRef]

16. Rahimi-Nasrabadi, M.; Ahmadi, F.; Eghbali-Arani, M. Simple Morphology-Controlled Fabrication of CdTiO3 Nanoparticles with the Aid of Different Capping Agents. J. Mater. Sci. Mater. Electron. 2016, 27, 13294-13299. [CrossRef]

17. Kooshki, H.; Sobhani-Nasab, A.; Eghbali-Arani, M.; Ahmadi, F.; Ameri, V.; Rahimi-Nasrabadi, M. Eco-Friendly Synthesis of PbTiO3 Nanoparticles and PbTiO3/Carbon Quantum Dots Binary Nano-Hybrids for Enhanced Photocatalytic Performance under Visible Light. Sep. Purif. Technol. 2019, 211, 873-881. [CrossRef]

18. Sobhani-Nasab, A.; Pourmasoud, S.; Ahmadi, F.; Wysokowski, M.; Jesionowski, T.; Ehrlich, H.; Rahimi-Nasrabadi, M. Synthesis and Characterization of MnWO4/TmVO4 Ternary Nano-Hybrids by an Ultrasonic Method for Enhanced Photocatalytic Activity in the Degradation of Organic Dyes. Mater. Lett. 2019, 238, 159-162. [CrossRef]

19. Sobhani-Nasab, A.; Behpour, M.; Rahimi-Nasrabadi, M.; Ahmadi, F.; Pourmasoud, S. New Method for Synthesis of BaFe12O19/Sm2Ti2O7 and BaFe12O19/Sm2Ti2O7/Ag Nano-Hybrid and Investigation of Optical and Photocatalytic Properties. J. Mater. Sci. Mater. Electron. 2019, 30, 5854-5865. [CrossRef]

20. Wang, F.M.; Li, B.H.; Luo, Z.D.; Liu, J.Q.; Sakiyama, H.; Ma, A.Q. Magnetism and Photocatalytic Degradation of Organic Dyes Based on a New Metal Formate Framework. Russ. J. Coord. Chem. 2018, 44, 415-420. [CrossRef]

21. Rahimi-Nasrabadi, M.; Behpour, M.; Sobhani-Nasab, A.; Jeddy, M.R. Nanocrystalline Ce-Doped Copper Ferrite: Synthesis, Characterization, and Its Photocatalyst Application. J. Mater. Sci. Mater. Electron. 2016, 27, 11691-11697. [CrossRef]

22. Rahimi-Nasrabadi, M.; Behpour, M.; Sobhani-Nasab, A.; Mostafa Hosseinpour-Mashkani, S. ZnFe2-xLaxO4 Nanostructure: Synthesis, Characterization, and Its Magnetic Properties. J. Mater. Sci. Mater. Electron. 2015, 26, 9776-9781. [CrossRef]

23. Wong, C.C.; Chu, W. The Hydrogen Peroxide-Assisted Photocatalytic Degradation of Alachlor in $\mathrm{TiO}_{2}$ Suspensions. Environ. Sci. Technol. 2003, 37, 2310-2316. [CrossRef] [PubMed]

24. Nguyen, A.T.; Juang, R.-S. Photocatalytic Degradation of P-Chlorophenol by Hybrid H2O2 and TiO2 in Aqueous Suspensions under UV Irradiation. J. Environ. Manag. 2015, 147, 271-277. [CrossRef] [PubMed]

25. Ahmed, K.E.; Kuo, D.-H.; Zeleke, M.A.; Zelekew, O.A.; Abay, A.K. Synthesis of Sn-WO3/g-C3N4 Composites with Surface Activated Oxygen for Visible Light Degradation of Dyes. J. Photochem. Photobiol. A Chem. 2019, 369, 133-141. [CrossRef]

26. Yemmireddy, V.K.; Hung, Y.-C. Using Photocatalyst Metal Oxides as Antimicrobial Surface Coatings to Ensure Food Safety-Opportunities and Challenges: Photocatalytic Antimicrobial Coatings. Compr. Rev. Food Sci. Food Safety 2017, 16, 617-631. [CrossRef]

27. Hosseinpour-Mashkani, S.S.; Sobhani-Nasab, A. Investigation the Effect of Temperature and Polymeric Capping Agents on the Size and Photocatalytic Properties of NdVO4 Nanoparticles. J. Mater. Sci. Mater. Electron. 2017, 28, 16459-16466. [CrossRef]

28. Huang, X.; Zhang, G.; Dong, F.; Tang, Z. The Remarkable Promotional Effect of Sn on $\mathrm{CeVO}_{4}$ Catalyst for Wide Temperature $\mathrm{NH}_{3}$-SCR Process by Citric Acid-Assisted Solvothermal Synthesis and Post-Hydrothermal Treatment. Catal. Sci. Technol. 2018, 8, 5604-5615. [CrossRef]

29. Ambard, C.; Duée, N.; Pereira, F.; Portehault, D.; Méthivier, C.; Pradier, C.-M.; Sanchez, C. Improvements in Photostability and Sensing Properties of EuVO4 Nanoparticles by Microwave-Assisted Sol-Gel Route for Detection of H2O2 Vapors. J. Sol Gel Sci. Technol. 2016, 79, 381-388. [CrossRef]

30. Basu, K.; Benetti, D.; Zhao, H.; Jin, L.; Vetrone, F.; Vomiero, A.; Rosei, F. Enhanced Photovoltaic Properties in Dye Sensitized Solar Cells by Surface Treatment of SnO2 Photoanodes. Sci. Rep. 2016, 6. [CrossRef]

31. Ge, X.; Zhang, Y.; Wu, H.; Zhou, M.; Lin, T. SmVO 4 Nanocrystals with Dodecahedral Shape: Controlled Synthesis, Growth Mechanism and Photoluminescent Properties. Mater. Res. Bull. 2018, 97, 81-88. [CrossRef]

32. Adib, K.; Rezvani, Z.; Rahimi-Nasrabadi, M.; Pourmortazavi, S.M. Statistically Optimized Synthesis of Cadmium Tungstate Nanoplates for Use as a Photocatalyst. J. Mater. Sci. Mater. Electron. 2018, 29, 6377-6387. [CrossRef] 
33. Aslam, I.; Cao, C.; Tanveer, M.; Farooq, M.H.; Khan, W.S.; Tahir, M.; Idrees, F.; Khalid, S. A Novel Z-Scheme $\mathrm{WO}_{3} / \mathrm{CdWO}_{4}$ Photocatalyst with Enhanced Visible-Light Photocatalytic Activity for the Degradation of Organic Pollutants. RSC Adv. 2015, 5, 6019-6026. [CrossRef]

34. Zhang, C.; Zhang, H.; Zhang, K.; Li, X.; Leng, Q.; Hu, C. Photocatalytic Activity of ZnWO $\mathrm{Zn}_{4}$ : Band Structure, Morphology and Surface Modification. ACS Appl. Mater. Interfaces 2014, 6, 14423-14432. [CrossRef] [PubMed]

35. Wang, Y.; Guan, X.; Li, L.; Lin, H.; Wang, X.; Li, G. Solvent-Driven Polymorphic Control of CdWO4 Nanocrystals for Photocatalytic Performances. New J. Chem. 2012, 36, 1852. [CrossRef]

36. Priya, A.M.; Selvan, R.K.; Senthilkumar, B.; Satheeshkumar, M.K.; Sanjeeviraja, C. Synthesis and Characterization of CdWO4 Nanocrystals. Ceram. Int. 2011, 37, 2485-2488. [CrossRef]

37. Maavia, A.; Aslam, I.; Tanveer, M.; Rizwan, M.; Iqbal, M.W.; Tahir, M.; Hussain, H.; Boddula, R.; Yousuf, M. Facile Synthesis of G-C3N4/CdWO4 with Excellent Photocatalytic Performance for the Degradation of Minocycline. Mater. Sci. Energy Technol. 2019, 2, 258-266. [CrossRef]

38. Malik, V.; Pokhriyal, M.; Uma, S. Single Step Hydrothermal Synthesis of Beyerite, $\mathrm{CaBi}_{2} \mathrm{O}_{2}\left(\mathrm{CO}_{3}\right)_{2}$ for the Fabrication of UV-Visible Light Photocatalyst BiOI/CaBi $\mathrm{O}_{2}\left(\mathrm{CO}_{3}\right)_{2}$. RSC Adv. 2016, 6, 38252-38262. [CrossRef]

39. Bhushan, M.; Kumar, Y.; Periyasamy, L.; Viswanath, A.K. Fabrication and a Detailed Study of Antibacterial Properties of $\alpha-\mathrm{Fe}_{2} \mathrm{O}_{3} / \mathrm{NiO}$ Nanocomposites along with Their Structural, Optical, Thermal, Magnetic and Cytotoxic Features. Nanotechnology 2019, 30, 185101. [CrossRef]

40. Lei, M.; Fu, C.; Cheng, X.; Fu, B.; Wu, N.; Zhang, Q.; Fu, A.; Cheng, J.; Gao, J.; Zhao, Z. Activated Surface Charge-Reversal Manganese Oxide Nanocubes with High Surface-to-Volume Ratio for Accurate Magnetic Resonance Tumor Imaging. Adv. Funct. Mater. 2017, 27, 1700978. [CrossRef]

41. Bogdan, J.; Pławińska-Czarnak, J.; Zarzyńska, J. Nanoparticles of Titanium and Zinc Oxides as Novel Agents in Tumor Treatment: A Review. Nanoscale Res. Lett. 2017, 12. [CrossRef] [PubMed]

42. Çeşmeli, S.; Biray Avci, C. Application of Titanium Dioxide $\left(\mathrm{TiO}_{2}\right)$ Nanoparticles in Cancer Therapies. J. Drug Target. 2019, 27, 762-766. [CrossRef] [PubMed]

43. Pan, X.; Wang, H.; Wang, S.; Sun, X.; Wang, L.; Wang, W.; Shen, H.; Liu, H. Sonodynamic Therapy (SDT): A Novel Strategy for Cancer Nanotheranostics. Sci. China Life Sci. 2018, 61, 415-426. [CrossRef] [PubMed]

44. Xu, P.; Wang, R.; Ouyang, J.; Chen, B. A New Strategy for TiO2 Whiskers Mediated Multi-Mode Cancer Treatment. Nanoscale Res. Lett. 2015, 10. [CrossRef] [PubMed]

45. Seidl, C.; Ungelenk, J.; Zittel, E.; Bergfeldt, T.; Sleeman, J.P.; Schepers, U.; Feldmann, C. Tin Tungstate Nanoparticles: A Photosensitizer for Photodynamic Tumor Therapy. ACS Nano 2016, 10, 3149-3157. [CrossRef]

46. AbuMousa, R.A.; Baig, U.; Gondal, M.A.; AlSalhi, M.S.; Alqahtani, F.Y.; Akhtar, S.; Aleanizy, F.S.; Dastageer, M.A. Photo-Catalytic Killing of HeLa Cancer Cells Using Facile Synthesized Pure and Ag Loaded WO3 Nanoparticles. Sci. Rep. 2018, 8. [CrossRef]

47. Han, B.; Popov, A.L.; Shekunova, T.O.; Kozlov, D.A.; Ivanova, O.S.; Rumyantsev, A.A.; Shcherbakov, A.B.; Popova, N.R.; Baranchikov, A.E.; Ivanov, V.K. Highly Crystalline $\mathrm{WO}_{3}$ Nanoparticles Are Nontoxic to Stem Cells and Cancer Cells. J. Nanomater. 2019, 2019, 1-13. [CrossRef]

48. Laulicht-Glick, F.; Wu, F.; Zhang, X.; Jordan, A.; Brocato, J.; Kluz, T.; Sun, H.; Costa, M. Tungsten Exposure Causes a Selective Loss of Histone Demethylase Protein. Mol. Carcinog. 2017, 56, 1778-1788. [CrossRef]

49. Hariani, P.L.; Faizal, M.; Ridwan, R.; Marsi, M.; Setiabudidaya, D. Synthesis and Properties of Fe3O4 Nanoparticles by Co-Precipitation Method to Removal Procion Dye. Int. J. Environ. Sci. Developm. 2013, 336-340. [CrossRef]

50. Guo, H.; Zhao, A.; He, Q.; Chen, P.; Wei, Y.; Chen, X.; Hu, H.; Wang, M.; Huang, H.; Wang, R. Multifunctional Fe3O4@mTiO2@noble Metal Composite NPs as Ultrasensitive SERS Substrates for Trace Detection. Arab. J. Chem. 2019, in press. [CrossRef]

51. Yang, S.; Zeng, T.; Li, Y.; Liu, J.; Chen, Q.; Zhou, J.; Ye, Y.; Tang, B. Preparation of Graphene Oxide Decorated $\mathrm{Fe}_{3} \mathrm{O}_{4} @ \mathrm{SiO}_{2}$ Nanocomposites with Superior Adsorption Capacity and SERS Detection for Organic Dyes. J. Nanomater. 2015, 2015, 1-8.

52. Huang, G.; Zhu, Y. Synthesis and Photocatalytic Performance of ZnWO4 Catalyst. Mater. Sci. Eng. B 2007, 139, 201-208. [CrossRef] 
53. Yan, T.; Li, L.; Tong, W.; Zheng, J.; Wang, Y.; Li, G. CdWO4 Polymorphs: Selective Preparation, Electronic Structures, and Photocatalytic Activities. J. Solid State Chem. 2011, 184, 357-364. [CrossRef]

54. Thirumalai, J.; Chandramohan, R.; Vijayan, T.A. A Novel 3D Nanoarchitecture of PrVO4 Phosphor: Selective Synthesis, Characterization, and Luminescence Behavior. Mater. Chem. Phys. 2011, 127, 259-264. [CrossRef]

55. Cao, J.; Xu, B.; Luo, B.; Lin, H.; Chen, S. Novel BiOI/BiOBr Heterojunction Photocatalysts with Enhanced Visible Light Photocatalytic Properties. Catal. Commun. 2011, 13, 63-68. [CrossRef]

56. Li, X.; Xu, H.; Li, C.; Qiao, G.; Farooqi, A.A.; Gedanken, A.; Liu, X.; Lin, X. Zinc-Doped Copper Oxide Nanocomposites Inhibit the Growth of Pancreatic Cancer by Inducing Autophagy Through AMPK/MTOR Pathway. Front. Pharmacol. 2019, 10, 319. [CrossRef] [PubMed]

(C) 2019 by the authors. Licensee MDPI, Basel, Switzerland. This article is an open access article distributed under the terms and conditions of the Creative Commons Attribution (CC BY) license (http://creativecommons.org/licenses/by/4.0/). 